\title{
The Relationship between Air Transport and Economic Growth in Turkey: Cross-Regional Panel Data Analysis Approach ${ }^{1}$
}

\author{
${ }^{*}$ NuriBaltaci, OzlemSekmen, GizemAkbulut \\ GumushaneUniversity,Turkey \\ *nbaltaci@gumushane.edu.tr
}

\begin{abstract}
Today, the economic and social effects of the airports on the region they are located are widely accepted throughout the world including Turkey. In developing countries transportation sector is a significant tool of development. Since millennium there has been a great growth in the number of people who prefer air transportation in Turkey. The decrease in the cost of the transportation of both passengers and freight in air transport leads the increase of its accessibility. In this concept when a region has an active airport it helps to increase the region's competitiveness and support its economic, social and cultural development. The aim of this study is to analyze whether an active airport and its traffic frequency have an effect on country's macroeconomic indicators. In this study region - fixed effect and two stage least square (2SLS) models are applied with using panel data for 26 sub-regions at NUTS 2 level in Turkey period of 2004 - 2011. The results of this study support that increasing in number of active airports and its traffic frequency have a positive effect on regional economic growth.
\end{abstract}

Keywords: Air Transportation, Regional Economic Growth, Panel Data

\section{Introduction}

The increase in trade through both interregional and inter-country demonstrates the importance of the transportation sector in terms of country economy with globalization. Airway is one of the ways which is used of moving and transporting both people and products or services from one place to another place with various purposes. Highway was the most commonly used access way during the first years of Turkish Republic. Therefore, airline transport sector had been developed in our country after State Airways was established in 1933. Service fee policies that are implemented by the airway companies lead people's attention to use airways and increase their demands due to the fact that the sector competition becomes very high because new airway companies are established. Furthermore, the increase in demand makes contribution to country's sustainable development and growth as affecting its macroeconomic indicators.Airline transportation affects the economy as creating many socioeconomic benefits in local economies thanks to hold distinguished characteristic features as speed, cost, comfort and security as well as providing employment opportunities for aviation industry. If the region is active in terms of economy, it provides capital and attends the needs of passenger travel and freight transport which constitute the demand for airline transportation services (Ishutkina, 2009).

A region's magnitude is also very important factor. According to region's magnitude, the possibility of making new economic activities to big regions in which a crowded population lives and there is a greater local market is higher than making them for a region which holds a relatively small population. Greater regions provide a broader local market potential for products and services as well as offer a better labor force possibilities (Button \& Taylor, 2000). In such ways, investments which are made in these kinds of convenient regions take important roles to develop both the country and the region.Generally, world economy will be growing annually average rate of 3.2\% within the following 20 years and the passenger traffic will be enhancing at a rate of $5.1 \%$ in the worldwide according to the assumptions of Boeing Company although negative situations in terms of economic, social, political etc. slow down the countries' development and growth speed. World economy will grow at a rate of 3.3\% while the passenger traffic will enhance with the rate of $4.7 \%$ annually according to Airbus Company. Furthermore, both companies claim that there is a quite close relationship between air transport and economic growth (Ministry of Transport, 2010).Economic and environmental effects of airports based on a region have been discussed widely in many countries with continuously increasing air traffic. These discussions emphasized the paradox where the first perspective is about airports' external negative effects like noise, pollution and

${ }^{1}$ This article is an expanded and revised version of report was presented at " 4 th International Conference on Economics, ICE-TEA" which held on 18-20 October 2014. 
safety problems which can occur for a region and the positive effects that support the region's economic activities. Economic benefits of the investments which are made for widening the airports are questioned for some cases on a national scale. Locating an airport in a small or stagnating domestic market can be beneficial due to its growth potential on the other hand it can be harmful due to itsexclusion effect (Hakfoortet a., 2001).

Passenger air transport investments can affect a regional economy in two different ways. First of all, airport will contribute additional income for local regional economy in that making new and direct investments to create employment opportunities and new buildings. Moreover, indirect and induced spending related to constant capital investments with large scale will create benefits for local economy development as creating various investment and external employment opportunities. Secondly, airline networks which are created by airlines can change a region's economic connections with other regions and countries. Therefore, building airline networks or connections strategically is expected to create competitive advantage over other regions which have access difficulties (Debbage, 1999).There were 40 active airports which had been opened for civil air traffic and were 67 airports totally if we include the military areas in the year of 2011, Turkey. There are 13 airline operating companies in civil aviation sector in Turkey and they also give cargo transportation services, too. In 2004, airline companies have 202 planes and this increased up to 346 in 2011. Plane traffic was approximately 641 thousand in 2004 and this doubled in 2011 rising to 1.331.835. Moreover, the passenger traffic which was about 45 million in 2004 increased to 118 million in 2011 (Directorate General of Civil Aviation, 2011).

Figure 1: The Relationship between Airline Transportation and Economic Growth in Turkey (2004-2011)

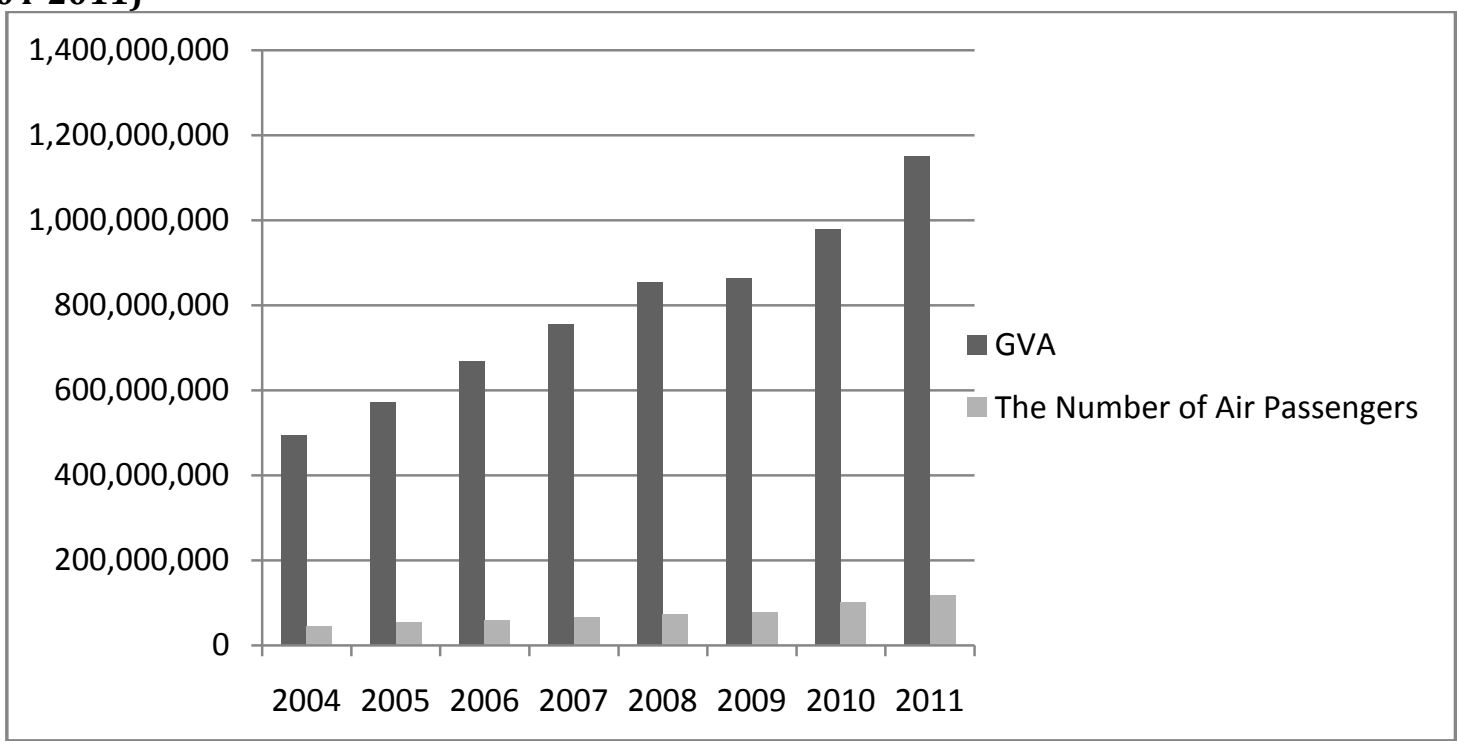

Source: TSI, 2014

The data of total number of airline passengers and Gross Value Added (GVA) as the indicator of economic growth take place in Graph 1 in order to evaluate the relationship between airline transportation and the economic growth for Turkey in the period of 2004-2011. In 2004, total airline passenger was 45 million while GVA was 495 million. As seen on the related graph, throughout the years a parallel growth has been occurred. While observing the 2011 total number of passengers reached 118 million as increasing steadily and total GVA approached to 1 billion 150 million TL. As verifying findings of Green study's (2007) it can be seen that there is a positive directed relationship between airline transport and economic growth in Turkey.

The number of total passengers, employment rate and GVA per capita variables of 26 sub-regions which belong to the period of 2004-2011 in Turkey Level-2 take place in Table-1. The number of total passengers which was about 15 million in 2004, dramatically increasing reached to nearly 51 million in 2011 in TR-10 region (Istanbul). The employment rate of the same region was 39, 6\% in 2004 and reached to $43,1 \%$. It is seen on the tablet that the regions TR42 (Kocaeli, Sakarya, Düzce, Bolu, Yalova) and TR81 (Zonguldak, Karabük, Bartın) began the air transport at the same period. TR21 (Tekirdağ, Edirne, Kırklareli) is the region which has the least airline and passenger traffic among the regions which 
had active airports in 2004 and continued operations in 2011. TR (10) Istanbul region had the highest GVA per capita for the period of 2004-2011. TRC3 (Mardin, Batman, Şırnak, Siirt) region was the one which had the least value of GVA per capita in 2004 while TRB2 (Van, Muş, Bitlis, Hakkâri) region took its place for 2011. Increases in GVA for regions happened at different rates with parallel to increase in number of total passengers could be seen when analyzing the GVA values in the regions generally. Furthermore, building a new airport or existing an airport in a region is quite important for the regional development.This study examines the relationship between air transport and regional economy for the regions of Turkey Level-2 during the period of 2004-2011 is consisted of 5 sections. Therefore, the data set is provided in section three after the subject related literature review is presented in section two. In section four, this study's methodology will be mentioned and empirical findings and conclusion will be provided in the last section.

Table 1:Turkey Level-2 Regions Airline Transportation Plane, Passenger Traffic Knowledge and GVA per Capita Data (2004-2011)

\begin{tabular}{|c|c|c|c|c|c|c|}
\hline \multirow[b]{2}{*}{ Level-2 Regions } & \multicolumn{3}{|l|}{2004} & \multicolumn{2}{|l|}{2011} & \multirow[b]{2}{*}{$\begin{array}{l}\text { GVA per } \\
\text { Capita } \\
\text { (TL) }\end{array}$} \\
\hline & $\begin{array}{l}\text { Total } \\
\text { Passenger } \\
\text { Amount }\end{array}$ & $\begin{array}{l}\text { Employment } \\
\text { Rate } \\
(\%)\end{array}$ & $\begin{array}{l}\text { GVA per } \\
\text { Capita } \\
\text { (TL) }\end{array}$ & $\begin{array}{l}\text { Total } \\
\text { Passenger } \\
\text { Amount }\end{array}$ & $\begin{array}{l}\text { Employment } \\
\text { Rate } \\
(\%)\end{array}$ & \\
\hline TR10 (Istanbul) & 15.600 .601 & 39,6 & 11.375 & 50.519 .36 & 43,1 & 23.247 \\
\hline $\begin{array}{l}\text { TR21 (Tekirdağ, Edirne, } \\
\text { Kirklareli) }\end{array}$ & 9.964 & 50,8 & 9.022 & 43.120 & 50,5 & 20.169 \\
\hline $\begin{array}{l}\text { TR22(Balıkesir, } \\
\text { Çanakkale) }\end{array}$ & 1.968 & 44,2 & 6.465 & 127.979 & 44,6 & 15.013 \\
\hline TR31 (İzmir) & 2.942 .281 & 38,5 & 9.448 & 8.523 .533 & 45,5 & 19.187 \\
\hline TR32 (Aydın, Denizli, Muğla) & 4.830 .197 & 51,1 & 7.618 & 7.295 .336 & 49,8 & 14.534 \\
\hline $\begin{array}{l}\text { TR33 (Manisa, Afyon, } \\
\text { UşakKütahya) }\end{array}$ & - & 44,2 & 5.789 & 15.267 & 50,2 & 13.888 \\
\hline TR41 (Bursa, Eskişehir, Bilecik) & 14.112 & 46,4 & 9.923 & 154.588 & 44,9 & 20.332 \\
\hline $\begin{array}{l}\text { TR42 (Kocaeli, Sakarya, Düzce, } \\
\text { Bolu, Yalova) }\end{array}$ & - & 36 & 10.286 & 11.851 & 48,2 & 22.028 \\
\hline TR51 (Ankara) & 3.275 .725 & 37,1 & 9.993 & 8.485 .467 & 43 & 20.554 \\
\hline TR52 (Konya, Karaman) & 94.676 & 38,3 & 5.567 & 600.871 & 46,1 & 11.935 \\
\hline TR61 (Antalya, Isparta, Burdur) & 13.659 .914 & 47,9 & 8.661 & 25.063 .346 & 52,6 & 16.972 \\
\hline TR62 (Adana, Mersin) & 1.147 .483 & 36,5 & 5.821 & 3.240 .967 & 46,4 & 12.125 \\
\hline $\begin{array}{l}\text { TR63 (Hatay, Osmaniye, } \\
\text { Kahramanmaraş) }\end{array}$ & - & 33,8 & 4.518 & 785.326 & 43,4 & 9.900 \\
\hline $\begin{array}{l}\text { TR71 (Kırıkkale, Aksaray, Niğde, } \\
\text { Nevşehir, Kırşehir) }\end{array}$ & 9.932 & 39,8 & 5.262 & 157.792 & 42,7 & 11.882 \\
\hline TR72 (Kayseri, Sivas, Yozgat) & 475.262 & 34,1 & 5.205 & 1.452.359 & 44,7 & 11.192 \\
\hline $\begin{array}{l}\text { TR81 (Zonguldak, Karabük, } \\
\text { Bartın) }\end{array}$ & - & 40,9 & 7.459 & 20.462 & 52,6 & 14.313 \\
\hline $\begin{array}{l}\text { TR82 (Kastamonu, Çankırı, } \\
\text { Sinop) }\end{array}$ & - & 34,1 & 5.984 & 58.438 & 56 & 11.057 \\
\hline $\begin{array}{l}\text { TR83 (Samsun, Tokat, Çorum, } \\
\text { Amasya) }\end{array}$ & 294.716 & 51,7 & 5.083 & 1.233 .709 & 49,7 & 11.338 \\
\hline $\begin{array}{l}\text { TR90 (Trabzon, } \\
\text { RizeGiresun, } \\
\text { Gümüşhane) }\end{array}$ & 775.699 & 61,3 & 5.076 & 2.280 .017 & 53,7 & 11.154 \\
\hline $\begin{array}{l}\text { TRA1 (Erzurum, Erzincan, } \\
\text { Bayburt) }\end{array}$ & 228.237 & 55,9 & 4.260 & 1.012 .411 & 47,3 & 9.893 \\
\hline $\begin{array}{l}\text { TRA2 (Ağrı, Kars, Iğdır, } \\
\text { Ardahan) }\end{array}$ & 95.857 & 43,4 & 2.933 & 512.103 & 48,8 & 6.708 \\
\hline $\begin{array}{l}\text { TRB1 (Malatya, Elazı̆̆, Bingöl, } \\
\text { Tunceli) }\end{array}$ & 179.237 & 35,9 & 4.320 & 1.119 .659 & 43,2 & 9.759 \\
\hline
\end{tabular}




\begin{tabular}{|c|c|c|c|c|c|c|}
\hline Level-2 Regions & $\begin{array}{l}\text { Total } \\
\text { Passeng } \\
\text { er } \\
\text { Amount }\end{array}$ & $\begin{array}{l}\text { Employment } \\
\text { Rate } \\
\text { (\%) }\end{array}$ & $\begin{array}{l}\text { GVA per } \\
\text { Capita } \\
\text { (TL) }\end{array}$ & $\begin{array}{l}\text { Total } \\
\text { Passenger } \\
\text { Amount }\end{array}$ & $\begin{array}{l}\text { Employment } \\
\text { Rate } \\
\text { (\%) }\end{array}$ & $\begin{array}{l}\text { GVA per } \\
\text { Capita } \\
\text { (TL) }\end{array}$ \\
\hline TRB2 (Van, Muş, Bitlis, Hakkari) & 197.571 & 36,1 & 2.688 & 1.253 .678 & 41,5 & 5.894 \\
\hline $\begin{array}{l}\text { TRC1 (Gaziantep, Adiyaman, } \\
\text { Kilis) }\end{array}$ & 411.213 & 35,3 & 3.835 & 1.359 .854 & 36,5 & 8.303 \\
\hline TRC2 (Şanlıurfa, Diyarbakır) & 522.445 & 32,6 & 3.404 & 1.964 .697 & 30,1 & 7.179 \\
\hline $\begin{array}{l}\text { TRC3 (Mardin, Batman, Şırnak, } \\
\text { Siirt) }\end{array}$ & 22.050 & 36,5 & 2.653 & 328.275 & 29,6 & 7.862 \\
\hline
\end{tabular}

Source: TSI, 2014

\section{Literature Review}

There are many studies focused on the relationship between air transport and economic growth in the literature. The results are relatively different due to using different data set, methodology and analyzing different time periods. The main intention of the study which was conducted by Goetz (1992) was to examine the relationship between air transport and the growth for 50 big USA metropolises. This relationship was investigated through Federal Aviation Administration and USA population census data about employment, changes in population and air passenger flow volume per person. The positive relationship expectation of higher volume of air passenger flow per person with both the previous and latter growth is supported the study's findings. The results obtained related to air transport and airport planning have sufficient reason of raising importance of providing needed airport structures and air services in addition to regenerate the important of air transport on economic development.State's function was increased in Bowen (2000) study which focused the relationship between air transport and economic growth Southeast Asia. The changes in habits of accessing to international airlines in Southeast Asia for the periods of 1979-1997 were investigated in the study. This study emphasized that national governments utilize some tools including giving freedom to airline sector and airport developments in order to reshape the air transport network improvements. The results of these strategies were evaluated using the network analysis.

Brueckner (2003) investigated the relationship between airline traffic in USA city centers and employment in the study. The study revealed evidences that the quality of airline service is an important factor on urban area development. Having an intense airline services to various regions facilitates face to face job interviews in different cities. Additionally, new built airports provide new business and employment facilities and this affect employment in the positive direction. 10\% increase in the passenger amount that use planes in the airports increases the employment at a rate of $1 \%$ in services sector according to empirical results of the study. However, it has not any effects over production sector. These assumptions were made through controlling the adverse causality among the employment and airline traffic.Yao and Yang (2008) examined the relationship between economic growth and the airport development of 31 cities and counties of China for the period of 1995-2006 in their study. There is a positive directed relationship among airport development and economic growth, industry structure, population density according to the results of the study. Air transport development is a warming factor for remote provinces due to its economic growth supporting function although decreases regional income and economic inequality of a country in general.

Fernandes and Pacheco (2010) examined the relationship between economic growth and national airline passenger transport in Brazil using Granger causality test in their study. The study includes the period of 1966-2006. GDP was considered as economic growth indicator and total national passenger- km values were regarded as airline access demand in the analysis. They reached the findings which support the hypothesis which claimed there is one directed Granger causality relationship from economic growth to national airline access as results of the study.Fernandes and Pacheco (2010) made Granger causality test using time series data for 1990-2009 in order to investigate the relationship between air transport and economic growth in their study. GDP was considered as economic growth indicator and total profit of air transport was used as showing the development of civil aviation transportation in the study. Economic 
growth affects considerably civil aviation development according the study results. Additionally, civil aviation development has powerful encouraging effect on economic growth.Florida et al. (2012) studied the role of airports on regional development within USA. They particularly focused on two aspects: firstly, the case of a metropolis' having an airport or not and secondly, airports effects on regional economic development. The data which belong to 2010 period were used for the multiple regression analysis. Whether a metropolis has an airport or not was used as a dependent variable dummy variable in the first module and GDP variable was used as a dependent variable as indicator of economic growth in the second module. Generally, the results are as follows, airports effects on regional development is equivalent to nearly human capital effects and has more dominant effects than advanced technologic sector.

The intention of Dharmawan's study (2012) is to investigate the relationship between airline traffic frequency and economic growth in Indonesia. The data which belong to the period of 2000-2010 were used for the analysis. After the analysis, there could found the results as thanks to tourism related sectors' contribution to airline usage, a positive relationship exists between airline transport and economic growth.According to Mukkala and Tervo (2013), there is no net causality relationship among the variables although they agreed upon the fact that there is a general strong relationship between airline traffic and economic growth. In their study, variables' structure was examined based on different regions in order to indicate the existence of the causality. The empiric analysis of the study depended on the data which belong to 13 countries and 86 regions with European level about regional economic performances and airline traffic for the period of 1991-2010. According to the results of the study, there is a causality in the direction from regional economic growth to increase in the number of people who prefer air transportation. Less evidences were found about causality relationship in the main regions although there is a causality relationship from airline traffic to regional economic growth in the around regions. Therefore, airline transport has important role on the development of remote areas.

Data Set: In this study, whether airline transport has role on regional economic growth or not is investigated through using panel data of Turkey Level-2 regions depending on the Statistical Classification of Territorial Units (SCTU) which belong to the period of 2004-2011.

Table 2:Summarizes the properties of variables used in the econometric model in this study

\begin{tabular}{llll}
\hline Variable & Definition of Variable & Type of Variable & Source of Variable \\
\hline GVA & Gross Value Added per capita & Dependent & Turkish Statistical \\
& with current prices (Turkish & Variable & Institution \\
Liras) & & &
\end{tabular}

Airline Traffic Plane amount that depart (Turkish + Foreign) and total number of passenger departing and arriving (External Line + Domestic Line).(Total/regional population)

Employment The labor force participation rate of the non-institutional population (15 years of age and over) (\%)

Education Number of students for vocational training school and undergraduate programs of higher education institutions (Graduates / Total )

Population Population( 15 years of age and over)

Migration

Airport

Provincial in-migration, out-migration, net-migration and net-migration rate according to Address Based Population Registration System.

Dummy variable takes the value of 1 in the years that there is at least one airport in sub-region while graded as 0 when there is not any airports.
Independent

variable-

Factor variable

Independent

variable

Independent

variable

Independent variable

Turkish Statistical Institution

Turkish Statistical Institution

Turkish Statistical Institution

Turkish Statistical Institution

Turkish Statistical Institution

variable

Dummy Variable

Turkish Statistical Institution 


\begin{tabular}{|c|c|c|c|}
\hline Variable & Definition of Variable & Type of Variable & Source of Variable \\
\hline Geographic & $\begin{array}{l}\text { Dummy variable, which takes the value } \\
\text { of } 1 \text { if sub-region is located in West } \\
\text { Turkey while takes the value of } 0 \text { if it is } \\
\text { located in East Turkey. }\end{array}$ & Dummy Variable & \\
\hline $\begin{array}{l}\text { International } \\
\text { airport }\end{array}$ & $\begin{array}{l}\text { Instrumental Variable takes the value of } \\
1 \text { when airports have international } \\
\text { access; otherwise they are defined as } \\
\text { dummy variable and take the value of } 0 .\end{array}$ & Dummy Variable & $\begin{array}{l}\text { General Directorate } \\
\text { of State Airports } \\
\text { Authority }\end{array}$ \\
\hline High Capacity & $\begin{array}{l}\text { Instrumental variable takes the value of } \\
0 \text { in the situations that total number of } \\
\text { passengers is less than } 1 \text { million in a one } \\
\text { year; otherwise it takes the value of } 1 \\
\text { when the passenger amount is greater } \\
\text { than } 1 \text { million. }\end{array}$ & Dummy Variable & $\begin{array}{l}\text { Directorate General } \\
\text { of Civil Aviation } \\
(2011) \text {. Directorate } \\
\text { General of Civil } \\
\text { Aviation's Annual } \\
\text { Report. }\end{array}$ \\
\hline
\end{tabular}

Gross Value Added: Gross Value Added (GVA) per capita is considered as dependent variable for this study. GVA is an important indicator for regions' economic outputs. The data used in this study which include regional GVA with current prices for the period of 2004-2011 for Turkey Level-2 regions are obtained through Turkish Statistical Institute (TSI) website. The data of GVA per capita is evaluated as dividing regions total population to the total GVA for those years.

Airline Traffic:Airline traffic is the related explanatory variable for this study. Airline traffic variable which is an indicator for airport existence and activities in a region is consisted of two standard decision makers which evaluates the airline activeness as one is plane amount that depart (Turkish + Foreign) and second is the departing and arriving passenger amount (External Line + Domestic Line). Both variables' data belong to 2004-2011 periods and to Turkey Level-2 regions. They are obtained from TSI and evaluated as per capita by having the regional population rate. Reducing both of the variables into one variable is feasible for the analysis (Srivastava, 2002). Adding two different variables, which define almost the same thing, to regression as independent variables can create problems about model assumption with causing the multiple direction levels and then this may cause to misinterpretation of the analysis results. Therefore, they combined into one variable as factor analysis method for two variables (Florida et al., 2012).

Control Variables: Other various variables of the economic growth are regarded as control variables in order to evaluate the relationship between airline transport development and regions' economic growth in this study. Demographic controls are added to the model as above 15 aged population (population) for 2004-2011 years in the related regions, net immigration speed (immigration speed) depending on the address based population registration system for 2008-2013 years, higher education graduates human capital (education) for 2004-2011 years. All the related data are obtained from TSI. No corporate population' (15 and above) rate to contribute workforce (employment) for the period of 2004-2011 is considered as economic control.

Dummy Variables: Dummy variable of airport existence is evaluated as if there is at least one airport in the region or not. Dummy variable takes the value of 1 in the years that there is at least one airport in sub-region while graded as 0 when there is not any airports. This situation is added to the analysis of airport activeness period effects. Geographic effect dummy variable, which is created for including the geographic regional effects to the analysis, takes the value of 1 if sub-region is located in West Turkey while takes the value of 0 if it is located in East Turkey.

Instrumental Variables: One of the factors that affect the airport traffic is the situation where international transport is performed in the airport in a region. International airport instrumental variable which reflects one of the most important specifications of the airports takes the value of 1 when airports have international access; otherwise they are defined as dummy variable and take the value of 0 .High capacity instrumental variable takes the value of 0 in the situations that passenger amount is less than 1 
million; otherwise it is considered as dummy variable and takes the value of 1 when the passenger amount is greater than 1 million.

Descriptive Statistics and Correlation Matrix: Descriptive statistics and correlation matrix related to the variables of the study are presented in Table- 3 and Table-4(see appendix). Therefore, there is a positive relationship between GVA per capita and airline transportation. Additionally, GVA per capita is directly proportional with human capital (higher education graduates). It could be said that a region's economic growth is tend to increase if higher education graduates population is higher. The positive relationship between airline traffic and employment can be interpreted as airline transportation sector positively contributed to employed people amount in the region. There found adverse relationship between almost all variables and population variable.

\section{Methodology}

Least Squares Method: Primarily, the effect of airline transport development on region's economic growth is determined via basic regression analysis using panel data for the period of 2004-2011 for Turkey Level-2 regions in this study.

GVA $_{i t}=\alpha+\beta$ airlinetraffic ${ }_{i t}+\gamma X_{i t}^{\prime}+\varepsilon_{i t}$

In the equation 1, GVA is a factor variable which included GVA per capita, airline traffic, and plane amount that totally departing from and arriving to the airport and passenger amount; and $\mathrm{X}$ is control variable vector. Human capital (higher education graduates), employment effects (the labor force participation rate), regional factors (population, immigration speed) are controlled. A region's locating in West or East Turkey and having an airport or not within the related periods are also controlled using dummy variables. It is tested whether the most intense airline traffic happens in West Turkey or not using geographic effect dummy variable.

Fixed Effects Model: The problem of no ability to control that variables related to dependent variable which affects the results is commonly experienced in regression assumptions. It is possible to control all the unobservable variables as adding the entire fixed effects to regression with panel data.Fixed effects model is used in order to take control of unobservable variables for the time of integrations after implementing least squares method in this study. Firstly, the necessity to use random effect or fixed effects model is determined by Haussmann test (Greene, 2003).There could be some possible variables that we could not observe andadd to the model while investigating the possible effects of airline transport on regional economy. There are some unobservable variables about gross value added and airline traffic although many demographic and economic factors are controlled. On the other hand, if the model included unobservable variables which follows the different time series, the fixed effects estimator would be biased. One of the useful solutions to these problems is to add time effects and region effects to the model.

The fixed effects model with time and region effects could be written as follows:

$G V A_{i t}=\alpha_{i}+\beta$ airlinetraffic $c_{i t}+\gamma X_{i t}^{\prime}+v_{i}+w_{t}+\delta_{i t}+\varepsilon_{i t}$

$\mathrm{v}_{\mathrm{i}}$ stands for region-specific error term which may have relationship between other explanatory variables, $\mathrm{w}_{\mathrm{t}}$ stands for time fixed effect, $\delta_{\mathrm{it}}$ stands for region-specific time trends in model 2.

Two Stage Least Squares Methods with Instrumental Variable Approach: The purpose of this study is to analyze the effects of airline transport on regional economy. Causality and endogenous issues should be taken into account although model parameters obtained statistically reasonable results after econometric tests results which are implemented till this section. The situation that economic growth makes airline transport accessible as decreasing its costs while the effects of airline transport on economic growth causes causality problem so that this interaction can be double directed. Ozcan (2012) implemented two stages least squares method (2SLS) in order to eliminate this problem.Generally speaking the 2SLS estimator can be categorized as a member of the family of Generalized Method of Moments (GMM) estimators. Efficient GMM provides an advantage of consistency in the presence of arbitrary heteroskedasticity, but at a cost of possibly poor finite sample performance. If the model has heteroskedasticity problem, the GMM estimator is more efficient than the simple IV estimator, otherwise the GMM estimator is no worse asymptotically than the IV estimator. Therefore, testing for the presence of heteroskedasticity when one or more variable is endogenous could be useful in deciding whether (2SLS) or GMM is called for Baum, Schaffer \&Stillman (2003). 
For this reason the White test is utilized to determine whether there is a heteroskedasticity problem or not with the equation. 2SLS model is found more appropriate than GMM based on the white test results and some advantages of have been mentioned above.Inconsistent estimators are obtained when basic 2SLS is implemented to the model if one or more of endogenous variables, which are located in the right side of any equations in a simultaneous model, are related to error term in the equation. One of the advantages of two stage least squares method is to deal with the endogenous problem (Bru eckner, 2003).

$G V A_{i t}=\alpha_{i}+$ Bairlinetraffic $c_{i t}+\gamma X_{i t}+\beta Z_{1}+\beta Z_{2}+\varepsilon_{i t}$

Airline traffic is endogenous variable and Z1 and Z2 are exogenous variables. Exogenous variable/ valid instrumental variable which is not included at least two models is needed for this model's assumption. Valid instrumental variables should be related to endogenous variable and not related to error term.Haussmann specification test is utilized to determine the necessity of using instrumental variable method instead of least squares method. Haussmann specification test results indicate that endogenous problem exists in the model, variables are affected from each other due to error terms and 2SLS is the most appropriate assumption method.

\section{Findings}

Least Squares Method: The regression results of basic least squares model which is implemented to determine the effects of airline transport development on regional economic growth as using panel data which belong to the period of 2004-2013 for Turkey Level-2 26 sub-regions are presented in this section. Table- 5 depicts the results of Least Squares model which is tested using the data of 26 regions which are located in Turkey Level-2. The parameter of gross value added which shows that there is relationship between the increase in airline transport and economic growth parameter is in the expected point and significant in $1 \%$ level.The results of the analysis which is made for the effects of active airport existence on the regional economy without using control and dummy variables can be found on the first column in the table. There is a positive and statistically meaningful relationship in 1\% level between GVA per capita and airport traffic per capita. $1 \%$ point increase in a region's airline traffic per capita causes $0.021 \%$ increase in GVA per capita when the rest is fixed.

Thereafter, demographic controls as higher education graduates and immigration speed are added to the equation (Column 2). The effect of education to regions value added is positive and statistically significant with $1 \%$ level. This result can also be interpreted as GVA tends to increase in the regions which generally educated people live. On the other hand, there is negative and statistically significant relationship between the increase in region population and GVA per capita.Last but not the least, all the control and dummy variables are added to the model (Column 3). Airline traffic variable parameter is still positive but become unreasonable statistically. Additionally, the employment rate in the region is positive and statistically reasonable with $10 \%$ level. $1 \%$ increase in employment rate cause the increase in GVA per capita at a rate of $0.0085 \%$ when all the rest is same.

Fixed Effects Model: The model which had been used till here dealt with only the changing variance problem. However, there is a possibility that standard errors can be autoregressive as time-wise.Fixed effects model is more effective than LS although LS method is helpful for many cases. The features of fixed effects model are defined as it facilitates to control unobservable regional heterogeneity and excluded variable biased.The results of fixed effects model are presented in Table- 6 . The entire control and dummy variables are excluded from the model in the first column of the table which the results of basic model which is included regional, time, regional directly time trend. Furthermore, $1 \%$ point increase in airline traffic per capita in the region can cause $0.017 \%$ increase in GVA per capita when everything else is constant.Dummy variable and the entire control variable excluding economic controls are added to the model in the second column of the table. Airline transport effect is still positive and statistically reasonable. When the rest is constant, $1 \%$ point increase in the airline traffic per capita causes the increase of GVA at a rate of $0.0025 \%$ after adding the demographic control and dummy variable into the model. This is less effective than the previous situation. Education's effect on regional development is unexpectedly negative and though statistically unreasonable.

Lastly, the results which are obtained after adding all the control variables and dummy variable into the model are illustrated in the Column 3. Population and immigration speed are remarkable as the statistically reasonable variables. The increase in the population and in net immigration speed of a region, 
which both of the variables have negative effects on the GVA per capita, affects the region's economic growth adversely. The airline traffic and education parameters are statistically unreasonable so that this makes meaningless to interpret them.R2 values, which is defined as the explanatory power of independent variable for dependent variable which being in the model for all the situations, are relatively high and as follows in order: $0.9458,0.9759,0.9762$.

Two Stage Least Squares Method with Instrumental Variables Approach: The assumption results related to two stage least square methods parameters are located in Table-7. Airline parameter is statistically unreasonable when excluding all the control and dummy variables from the model in the table's first column.Dummy variable and the entire control variable excluding economic controls are added to the model in the second column of the table. Airline transport effect is still positive and statistically reasonable. When the rest is constant, $1 \%$ point increase in the airline traffic per capita causes the increase of GVA at a rate of $0.0166 \%$ after adding the demographic control and dummy variable into the model. As expected, the effect of the education on the regional development is positive and statistically meaningful. Furthermore, $1 \%$ point increase in university graduates in the region causes the increase at a rate of $0.0000089 \%$ in the region's value added when everything else is constant. Additionally, population increase has negative effect in the increase of the region's value added.Lastly, the results which are obtained after adding all the control variables and dummy variable into the model are illustrated in the Column 3. Airline transport effect is still positive and statistically reasonable. $1 \%$ point increase in the airline traffic can cause the increase of region's value added at a rate of $0.0174 \%$. Education's effect on the region's economic growth is found as positive with the same parameters in the Column 2 and statistically reasonable. $1 \%$ point increase in the employment contributes to the region's economic growth at a rate of $0.00652 \%$.

\section{Conclusion}

Airline transport is taken into account as a very effective factor on explaining countries' economic growths. In particularly, there are dramatically increases in airline traffic in the developing countries. Through this way, the purpose of this study is to investigate the effects of having an active airport in a region on the regional economic growth. The result is obtained after related literature review that airline transport has importance when taking economic activities decisions. As a result of the study, findings are obtained with parallel to the literature as accepting the general opinion that airline transport is an important factor which positively affects the regions' economic growth. This result is an important indicators of economic growth especially in developing countries. In this context, in further study the relationship between airway traffic and economic growth will be re-explored and accuracy of this study will be tested with a case of new airports, such as $3^{\text {rd }}$ airport in Istanbul, will be built in different region in Turkey.

\section{References}

Bowen, J. (2000). Airline hubs in Southeast Asia: national economic development and nodal accessibility.Journal of Transport Geography, 8(1), 25-41.

Brueckner, J. K. (2003). Airline Traffic and Urban Economic Development.Urban Studies, 40(8), 14551469.

Button, K. \& Taylor, S. (2000). International Air Transportation and Economic Development.Journal of Air Transport Management, 6(4), 209-222.

Debbage, K. (1999). Air transportation and urban-economic restructuring: competitive advantage in the US Carolinas.Journal of Air Transport Management, 5, 211-221.

Dharmawan, I. G. N. I. (2012). The Effect of Air Transport to Economic Development in Indonesia, Erasmus University.

Fernandes, E. \& Pacheco, R. R (2010). The causal relationship between GDP and domestic air passenger traffic in Brazil.Transportation Planning and Technology, 33(7), 569-581.

Florida, R., Mellander, C. \&Holgersson, T. (2012). Up in the air: The role of airports for regional economic development, Royal Institute of Technology, Paper No. 267, CESIS-Centre of Excellence for Science and Innovation Studies.

Goetz, A.R. (1992). Air Passenger Transportation and Growth in the US Urban System, 1950-1987.Growth and Change, 23, 218-242.

Hakfoort, J., Poot, T. \&Rietveld, P. (2001). The regional economic impact of an airport: the case of Amsterdam Schiphol Airport.Regional Studies, 35(7), 595-604. 
Ishutkına, M. A. (2009). Analysis of the interaction between air transportation and economic activity: a worldwide perspective, PhD Thesis, Massachusetts Institute of Technology Cambridge, MA 02139 USA.

Mukkala, K. \&Tervo, H. (2013). Air Transportation And Regional Growth: Which Way Does The Causality Run?Environment and Planning A, 45(6), 1508-1520.

Ozcan, I.C. (2012). The effect of air cargo traffic on regional job creation in Turkey, unpublished working paper.

Directorate General of Civil Aviation. (2011). Directorate General of Civil Aviation's Annual Report.

Srivastava, M. S. (2002). Methods of Multivariate Statistics. New York: Wiley.

TSI. (2014).http://tuikapp.tuik.gov.tr/Bolgesel/anaSayfa.do, (Access Date: 20/08/2014).

Republic of Turkey Ministry of Transport, Maritime Affairs and Communications(2010).www.ubak.gov.tr/BLSM.../tr/.../20100518_171202_204_1_64.pdf

Greene, W. H. (2008). Econometric analysis. Granite Hill Publishers.

Yao, S. \& Yang, X. (2008). Airport development and regional economic growth in China, Research Paper Series, University of Nottingham.

\section{APPENDIX}

Table 3:Descriptive Statistics

\begin{tabular}{|c|c|c|c|c|c|c|c|c|c|c|c|c|}
\hline \multicolumn{3}{|c|}{ Variables } & \multicolumn{3}{|c|}{ Observe Amount } & \multicolumn{2}{|l|}{ Average } & \multicolumn{2}{|c|}{ Standard Error } & \multicolumn{2}{|l|}{ Min. } & Max. \\
\hline \multicolumn{3}{|c|}{ GVA (per capita) } & \multicolumn{2}{|c|}{208} & & \multicolumn{2}{|l|}{13.17618} & \multicolumn{2}{|c|}{5.37283} & \multicolumn{2}{|l|}{.1210763} & 31.969947 \\
\hline \multicolumn{3}{|c|}{$\begin{array}{l}\text { Passenger Amount } \\
\text { (per capita) }\end{array}$} & \multicolumn{3}{|l|}{234} & \multicolumn{2}{|l|}{.0096748} & \multicolumn{2}{|l|}{.0148581} & 0 & & .0885031 \\
\hline \multicolumn{3}{|c|}{$\begin{array}{l}\text { Plane Amount } \\
\text { (per capita) }\end{array}$} & \multicolumn{3}{|l|}{234} & \multicolumn{2}{|l|}{1.074181} & \multicolumn{2}{|l|}{2.101551} & \multicolumn{2}{|l|}{0} & 12.76138 \\
\hline \multicolumn{3}{|c|}{$\begin{array}{l}\text { Airline Traffic } \\
\text { (per capita) }\end{array}$} & \multicolumn{3}{|l|}{234} & \multicolumn{2}{|l|}{$5.97 e-11$} & \multicolumn{2}{|l|}{.9896286} & \multicolumn{2}{|l|}{.5781056} & 5.404914 \\
\hline \multicolumn{3}{|c|}{ Education } & 234 & & & 16146.45 & & 25111.41 & & 1346 & & 195593 \\
\hline Popı & ation & & 260 & & & 2399954 & & 6975223 & & 536000 & & $1.11 \mathrm{e}+08$ \\
\hline $\mathrm{Imm}$ & sration & peed & 156 & & & 0 & & 23810.44 & & -60175 & & 121782 \\
\hline Emp & yment & $\%)$ & 260 & & & 47.90154 & & 6.664769 & & 28.8 & & 65.8 \\
\hline Airp & rt exist & hce & 260 & & & .9307692 & & .2543357 & & 0 & 1 & 1 \\
\hline Geog & aphy & & 260 & & & .5384615 & & .49948 & & 0 & 1 & 1 \\
\hline Intel & Iational & Airport & 260 & & & .65 & & .4778895 & & 0 & 1 & 1 \\
\hline Pass & nger Ca & acity & 260 & & & .4230769 & & .4950002 & & 0 & 1 & 1 \\
\hline & GVA C & PAC & Pl. AC & ATC & Ed. & PP & IS & E.(\%) & $\mathbf{A E}$ & Gpy & IA & PC \\
\hline $\begin{array}{l}\text { GVA } \\
\text { C } \\
\text { PAC }\end{array}$ & $\begin{array}{l}1.0000 \\
0.4318\end{array}$ & 1.0000 & & & & & & & & & & \\
\hline $\begin{array}{l}\text { Pl. } \\
\text { AC }\end{array}$ & 0.3421 & 0.9791 & 1.0000 & & & & & & & & & \\
\hline ATC & 0.3893 & 0.9948 & 0.9947 & 1.0000 & & & & & & & & \\
\hline $\begin{array}{l}\text { Ed. } \\
\text { PP }\end{array}$ & $\begin{array}{l}0.5142 \\
-\end{array}$ & $\begin{array}{l}0.0393 \\
-\end{array}$ & $\begin{array}{l}0.0198 \\
-\end{array}$ & $\begin{array}{l}0.0298 \\
-\end{array}$ & $\begin{array}{l}1.0000 \\
0.0015\end{array}$ & 1.0000 & & & & & & \\
\hline IS & $\begin{array}{l}0.1805 \\
0.7783\end{array}$ & $\begin{array}{l}0.0073 \\
0.5011\end{array}$ & $\begin{array}{l}0.0049 \\
0.4216\end{array}$ & $\begin{array}{l}0,0061 \\
0.4641\end{array}$ & 0.4309 & 0.0663 & 1.0000 & & & & & \\
\hline $\begin{array}{l}\text { E. } \\
(\%)\end{array}$ & 0.3382 & 0.2749 & 0.2580 & 0.2679 & 0.0353 & $\begin{array}{l}- \\
0.1938\end{array}$ & 0.1577 & 1.0000 & & & & \\
\hline $\mathrm{AE}$ & $\overline{-}-1232$ & 0.1387 & 0.1095 & 0.1249 & 0.0177 & 0.0276 & $\overline{-}-1085$ & $\overline{-}-1173$ & 1.0000 & & & \\
\hline Gpy & 0.6624 & 0.2709 & 0.2311 & 0.2524 & 0.3379 & $\overline{-}-0576$ & 0.5626 & 0.4177 & $-\overline{0.1852}$ & 1.0000 & & \\
\hline IA & 0.1300 & 0.1750 & 0.1891 & 0.1829 & 0.2199 & 0.0972 & 0.1025 & 0.1739 & 0.1852 & $\overline{-} .0063$ & 1.0000 & \\
\hline PC & 0.0237 & 0.1558 & 0.1185 & 0.1380 & $\begin{array}{l}- \\
0.0768\end{array}$ & 0.0207 & 0.0791 & $\begin{array}{l}- \\
0.1465\end{array}$ & 0.1747 & 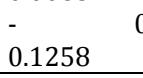 & 0.1291 & 1.0000 \\
\hline
\end{tabular}


GVAC: GVA per capita, PAC: Passenger Amount per capita, Pl. AC: Plane Amount per capita, ATC: Airline Traffic per capita, Ed.: Education, PP: population, IS: Immigration Speed, E (\%):Employment (\%), AE: Airport existence, Gpy: Geography, IA: International Airport, PC: Passenger Capacity

Table 5: Regression Parameters for the effect of airline Transport on Economic Growth OLS Dependent Variable : GVA (per capita)

OLS

\begin{tabular}{|c|c|c|c|c|}
\hline (1) & (2) & & (3) & \\
\hline $\begin{array}{lll}\begin{array}{l}\text { Airline } \\
\text { capita) }\end{array} & \text { Traffic } & \text { (per } \\
\end{array}$ & $\begin{array}{l}2.103519 \\
(0.00)\end{array}$ & $* * *$ & $\begin{array}{l}.4033641^{*} \\
(0.095)\end{array}$ & $\begin{array}{l}2691773 \\
(0.396)\end{array}$ \\
\hline Education & & & $\begin{array}{l}.0000394^{* * *} \\
(0.001)\end{array}$ & $\begin{array}{l}.0000402^{* * *} \\
(0.001)\end{array}$ \\
\hline Population & & & $-9.98008^{* * *}(0.001)$ & $\begin{array}{l}-9.2108^{* * *} \\
(0.001)\end{array}$ \\
\hline Immigration Speed & & & $\begin{array}{l}.000109 * * * \\
(0.000)\end{array}$ & $\begin{array}{l}.0001133^{* * *} \\
(0.000)\end{array}$ \\
\hline Employment (\%) & & & & $\begin{array}{l}0847025^{*} \\
(0.084)\end{array}$ \\
\hline Dummy & NO & & YES & YES \\
\hline $\mathrm{N}$ & 208 & & 104 & 104 \\
\hline $\mathrm{R}^{2}$ & 0.1417 & & .7512 & 0.7588 \\
\hline
\end{tabular}

***, ${ }^{* *}$, and ${ }^{*}$ show the meaningfulness levels in $\% 1,5$, and 10 levels. P value is shown in the brackets.

Table 6:Regression Parameters for the effect of airline Transport on Economic Growth Fixed Effects

\section{Dependent Variable: GVA}

FIXED EFFECTS: ( with regional, time, regional directly time trend)

\begin{tabular}{llll}
\hline & $(1)$ & $(2)$ & $(3)$ \\
\hline AIRLINE TRAFFIC & $1.690918^{* *}$ & $.025207^{*}$ & -.073178 \\
& $(0.058)$ & $(0.980)$ & $(0.944)$ \\
EDUCATION & & -.0000259 & -.0000244 \\
& & $(0.138)$ & $(0.169)$ \\
POPULATION & & $-1.0007^{* * *}$ & $-1.0207^{* * *}$ \\
& & $(0.000)$ & $(0.000)$ \\
IMMIGRATION SPEED & & $.0000271^{* *}$ & $.0000269^{*}$ \\
& & $(0.013)$ & $(0.014)$ \\
IMPLOYMENT & & & .0395841 \\
& $\mathrm{NO}$ & & $(0.482)$ \\
DUMMY & 208 & YES & YES \\
$\mathrm{N}$ & 0.9458 & 104 & 104 \\
$\mathrm{R}^{2}$ & & 0.9759 & 0.9762 \\
\hline
\end{tabular}

$* * *, * *$, and ${ }^{*}$ show the meaningfulness levels in $\% 1,5$, and 10 levels. P value is shown in the brackets. 
Table 7: Regression Parameters for the effect of Airline Transport on Economic Growth 2 Stage Least Square (2SLS) - IV

Dependent Variable: GVA (per capita)2SLS

\begin{tabular}{|c|c|c|c|}
\hline (1) & (3) & & \\
\hline $\begin{array}{lll}\begin{array}{l}\text { Airline } \\
\text { capita) }\end{array} & \text { Traffic } & \text { (per } \\
\end{array}$ & $\begin{array}{l}1.948051 \\
(0.255)\end{array}$ & $\begin{array}{l}.1 .664724^{*} \\
(0.121)\end{array}$ & $\begin{array}{l}1.744359^{*} \\
(0.142)\end{array}$ \\
\hline Education & & $\begin{array}{l}000089 \text { *** } \\
(0.000)\end{array}$ & $\begin{array}{l}.0000896^{* * *} \\
(0.000)\end{array}$ \\
\hline Population & & $\begin{array}{l}-4.9808^{*} \\
(0.138)\end{array}$ & $\begin{array}{l}-4.3808 \\
(0.203)\end{array}$ \\
\hline Immigration Speed & & $\begin{array}{l}.000109^{* * *} \\
(0.000)\end{array}$ & $\begin{array}{l}.0001133^{* * *} \\
(0.000)\end{array}$ \\
\hline Employment (\%) & & & $\begin{array}{l}.0652146 \\
(0.006)\end{array}$ \\
\hline Dummy & YOK & VAR & VAR \\
\hline $\mathrm{N}$ & 208 & 208 & 208 \\
\hline $\mathrm{R}^{2}$ & 0.1409 & 0.5372 & 0.5418 \\
\hline
\end{tabular}

$* * *, * *$, and $*$ show the meaningfulness levels in $\% 1,5$, and 10 levels. P value is shown in the brackets. 